\title{
KONSTYTUCYJNE UWARUNKOWANIA STABILNOŚCI RADY MINISTRÓW
}

I. Konstytucja jest najwyższym prawem Rzeczypospolitej, przesądza o tym art. 8 Konstytucji RP, formułując w polskim porządku prawnym zasadę konstytucjonalizmu ${ }^{1}$. To właśnie przepisy Konstytucji mają najwyższą moc prawną w całym systemie prawa stanowionego ${ }^{2}$ i to one determinują zasady funkcjonowania państwa ${ }^{3}$. Szczególnie istotną wartością dla wspólnoty politycznej - i to niezależnie od tego, jaka to jest wspólnota i na jakim poziomie zorganizowania społecznego wspólnota ta funkcjonuje - jest niewątpliwie sam fakt istnienia i konieczność zapewnienia dalszego jej trwania. Dla realizacji tego celu musi więc funkcjonować instytucja władzy, której istnienie jest konieczne dla zapewnienia ochrony bytu wspólnoty .

Doświadczenie historyczne uczy przy tym, jak niebezpieczna dla wspólnoty politycznej jest niestabilność władzy najwyższej. Wydaje się, że najdobitniej zostało to ukazane w okresie III i IV Republiki Francuskiej, kiedy to w latach 1875-1940 Francją rządziło 100 ekip rządowych, a w latach 1946-1958 - aż $24^{5}$. Realizowany wówczas sposób funkcjonowania władzy wykonawczej pozwolił na sformułowanie przez René Capitanta tezy o braku rzeczywistej de-

\footnotetext{
${ }^{1}$ Należy jednak podkreślić, że konstytucjonalizmu nie można sprowadzać do faktu uchwalenia i funkcjonowania w danym kraju konstytucji. Konstytucjonalizm to model ustrojowy kształtujący się już od dawna, w literaturze przedmiotu podkreśla się nawet, że „początki konstytucjonalizmu są tak stare jak samo państwo, bo wiążą się z myślą o koniecznych granicach władzy państwowej”, A. Pułło, Idee konstytucjonalizmu i państwa konstytucyjnego, „Gdańskie Studia Prawnicze" 24, 2010, s. 419. O możliwych sposobach definiowania i rozumienia pojęcia konstytucjonalizmu zob. szerzej W.J. Wołpiuk, Prawo. Kultura prawna, zaufanie do prawa, Wrocław 2016, s. 182.

${ }^{2}$ Konstytucja jest więc normą norm prawnych (zob. A. Rzepliński, Katalog zasad naczelnych $w$ Konstytucji RP $i$ system źródet prawa a praktyka, w: P. Zientarski (red.), Konstytucja jako fundament państwa prawa. W 15. rocznice uchwalenia Konstytucji Rzeczypospolitej Polskiej, Warszawa 2013, s. 27) i to właśnie ona określa porządek prawny i porządek państwowy (zob. H. Kelsen, Istota i rozwój sqdownictwa konstytucyjnego, Warszawa 2009, s. 21).

${ }^{3}$ Należy przy tym pamiętać, że Konstytucja nie jest wyłącznie „formalnoprawną podstawa całego systemu prawa obowiązującego, aktem określającym sposób powołania i ustrój organów państwa, ale przede wszystkim aktem wyrażającym podstawowe wartości, na których system prawa jest oparty", P. Tuleja, Stosowanie Konstytucji RP $w$ świetle zasady jej nadrzędności (wybrane problemy), Kraków 2003, s. 64.

${ }^{4}$ „Państwo jest taką wspólnotą ludzka, która w obrębie określonego terytorium rości sobie (z powodzeniem) prawo monopolu na wywieranie prawomocnej przemocy fizycznej”, M. Weber, Polityka jako zawód i powołanie, Kraków, Warszawa 1998, s. 56.

${ }^{5}$ Dane za: E. Popławska, Instytucja prezydenta w systemie politycznym V Republiki Francuskiej, Warszawa 1995, s. 15.
} 
mokracji i zastapieniu suwerenności narodu przez „suwerenność” parlamentu, a w konsekwencji utracie legitymizacji społecznej przez reżym ${ }^{6}$. Również włoskie doświadczenia po II wojnie światowej były niepokojace. W konsekwencji niestabilnego systemu politycznego oraz regulacji konstytucyjnej, która nie gwarantowała stabilności rządów, w latach 1945-1988 było we Włoszech aż 48 ekip rządowych ${ }^{7}$. Trudno w takich warunkach mówić o możliwości sprawnego rządzenia państwem i możliwości podejmowania koniecznych decyzji ${ }^{8}$. Należy także pamiętać o typowych interakcjach zachodzących w państwie - brak stabilnego rządu rodzi kryzysy gospodarcze i społeczne, ale i istniejaccy kryzys społeczny i gospodarczy może być powodem - a często i koniecznością - zmian na najwyższych szczeblach władzy. Dla uniknięcia niestabilności rządów, ale i dla ograniczenia potencjalnego źródła kryzysu szczególnie ważne jest więc takie zdefiniowanie układu władzy w państwie, aby przy zachowaniu przyjętych zasad konstytucyjnych zapewnić także pożądaną stabilność i efektywność władzy wykonawczej.

II. Stabilność władzy wykonawczej jest tylko jednym z elementów szerszego pojęcia, jakim jest stabilność polityczna państwa. Pojęcie to bywa różnie definiowane. G. Bingham Powell uważał, że na stabilność polityczna państwa wpływ mają trzy elementy: partycypacja obywatelska w wyborach, stabilność rządu i porządek polityczny ${ }^{9}$. Natomiast Allison McCulloch podkreślała, że pojęcie to jest trudne do jednoznacznego zdefiniowania, ale sprowadza się do takiego funkcjonowania państwa, w którym nie tylko nie dochodzi do wybuchów przemocy, ale i funkcjonuje określony porządek publiczny (civil order $)^{10}$. W tym rozumieniu stabilność polityczna łączona jest ściśle z trwałością rządu (czy też szerzej - z trwałością władzy najwyższej w państwie), jego efektywnością działania, jak również legitymizacją reżymu konstytucyjnego i brakiem dokonujących się zmian strukturalnych ${ }^{11}$.

W literaturze przedmiotu ${ }^{12}$ podkreśla się, że szczególne wątpliwości w zaprezentowanej powyżej definicji budzi wymóg powstrzymywania się od do-

${ }^{6}$ Zob. R. Capitant, Écrits constitutionnels, Paris 1982, s. 357, za: E. Popławska, op. cit., s. 15.

7 Zob. P. Furlong, Government stability and electoral systems. The Italian example, „Parliamentary Affairs" 44(1), 1991, s. 50.

${ }^{8}$ Niekiedy jednak w doktrynie można spotkać się z poglądem, że łączenie niestabilności rządu z kwestią stabilności politycznej państwa jest niewłaściwe, gdyż w większości systemów z pozornie niestabilnymi gabinetami istnieje bardzo stabilny "rdzeń« personelu ministerialnego". Tak Arend Lijphart relacjonuje stanowisko Mattei Dogana (M. Dogan, Irremovable leaders and ministerial instability in European democracies, w: idem (ed.), Pathways to Power: Selecting Rulers in Pluralist Democracies, Boulder 1989, s. 239 i n.); zob. A. Lijphart, Patterns of Democracy. Government Forms and Performance in Thirty-Six Countries, London-New Haven 2012, s. 118.

${ }^{9}$ Zob. G.B. Powell, Contemporary Democracies. Participation Stability and Violence, Cambridge 1982 , s. 8.

10 A. McCulloch, Does moderation pay? Centripetalism in deeply divided societies, „Ethnopolitics" 12(2), 2013, s. 115.

11 Ibidem; L. Hurwitz, Contemporary Approaches to Political Stability, „Comparative Politics” 5(3), 1973, s. 449.

12 W literaturze polskiej zob. K. Trzciński, Czym jest stabilność polityczna państwa?, „Przegląd Politologiczny” 2015, nr 2, s. 39. 
konywania zmian strukturalnych jako elementu niezbędnego dla uznania istnienia stabilności politycznej państwa. W tym rozumieniu bowiem nawet wprowadzenie zmian demokratyzujacych system (przejście z reżymu autorytarnego do demokratycznego) byłoby uznane za przejaw niestabilności państwa $^{13}$. Musimy jednak uwzględnić, że pojęcie „stabilność państwa” winno być rozpatrywane jako pojęcie emocjonalnie neutralne. W takim przypadku nie będzie budzić wątpliwości, że państwo stabilne to takie, które trwa przez lata w określonym przez swoje normy ustrojowe reżymie politycznym i nie ma $\mathrm{w}$ tym zakresie potrzeby dokonywania zmian strukturalnych.

III. W polskim modelu rządów - określanym w doktrynie jako zmodyfikowany system parlamentarny ${ }^{14}$ - władza wykonawcza została ukształtowana jako dualistyczna, w jej skład wchodzi Prezydent RP oraz organ kolegialny w postaci Rady Ministrów ${ }^{15}$. Z uwagi na fakt wyboru Prezydenta RP w drodze wyborów powszechnych i braku możliwości jego odwołania (poza konstytucyjnie zdefiniowaną odpowiedzialnością konstytucyjna) rozważania w niniejszym tekście dotyczące stabilności funkcjonowania władzy wykonawczej odnosić się będą do kolegialnego członu egzekutywy - rządu.

Stabilność - definiowana słownikowo jako „trwałość”, „niezmienność”, „nieruchomość” 16 - funkcjonowania rządu nie została ujęta expressis verbis w regulacjach konstytucyjnych, musi więc być dekodowana w drodze analizy całości regulacji dotyczących powoływania i funkcjonowania Rady Ministrów ${ }^{17}$. Należy więc przyjąć, że stabilność funkcjonowania rządu będzie rozpatrywana jako jego trwanie - niezmienność istnienia w określonym układzie politycznym, który przyczynił się do jego powstania.

13 Ibidem.

14 Janusz Trzciński i Małgorzata Masternak-Kubiak twierdzą: „Przyjęty w Konstytucji RP z 2 kwietnia 1997 r. system rządów, pomimo czynionych zastrzeżeń, jest systemem parlamentarnym, co oznacza, że konstytucja eksponuje wśród organów państwa pozycję Sejmu, respektując jednocześnie podstawowe instytucje uważane za charakterystyczne dla zasady podziału władzy, tzn. przewiduje nie tylko separację władz, ale i elementy współdziałania” (eidem, System rzadów w Konstytucji Rzeczypospolitej Polskiej z 2 kwietnia 1997 r. - analiza kompetencji Sejmu, „Przegląd Sejmowy” 1997, nr 5(22), s. 53. Zob. także J. Trzciński, Nowa konstytucja - system rzadów parlamentarnych, w: K. Działocha (red.), Przeobrażenia we wspótczesnym prawie konstytucyjnym, Wrocław 1995, s. 81-85.

15 Organ ten określany jest jako „rząd”, i tak też - zamiennie - będzie nazywany w niniejszym opracowaniu, jednakże należy uwzględnić, że to Konstytucja RP z 1997 r. dokonała istotnej zmiany w używanej nomenklaturze. W poprzedniej regulacji konstytucyjnej - Małej Konstytucji z 1992 r. - tytuł rozdziału 4 brzmiał: „Rada Ministrów Rzeczypospolitej Polskiej (rząd)”. O konsekwencjach dokonanej zmiany zob. R. Balicki, w: M. Haczkowska (red.), Konstytucja Rzeczypospolitej Polskiej. Komentarz, Warszawa 2014, s. 359 (i wskazana tam literatura).

16 Zob. Stownik języka polskiego, t. 8, red. W. Doroszewski, Warszawa 1966, s. 674.

17 Analiza taka musi obejmować nie tylko normy prawne, lecz także konstytucyjną praktykę ich stosowania, a także - zdaniem Marii Kruk - nie można pomijać elementów, o których Konstytucja nie wspomina, a są one niezwykle istotne dla tytułowego zagadnienia (jak np. proces budowania koalicji większościowej); zob. eadem, Idea stabilności i efektywności rzadów w Konstytucji $R P$ z 1997 r., w: W. Czapliński (red.), Prawo w XXI wieku. Księga pamiqtkowa 50-lecia Instytutu Nauk Prawnych Polskiej Akademii Nauk, Warszawa 2006. 
IV. Powoływanie rządu w Konstytucji RP z 1997 r. - pomimo zmian upraszczających, w porównaniu z regulacją Małej Konstytucji z 1992 r. ${ }^{18}-$ jest procedurą wieloetapową i angażuje w swój przebieg różne ośrodki polityczne. Jednakże to właśnie dzięki tej złożoności Rada Ministrów powołana w zgodzie z konstytucyjnymi regulacjami ma możliwość sprawnego i stabilnego funkcjonowania.

Konstytucja z 1997r.zdefiniowała trzy tryby tworzenia Rady Ministrów.Trybem podstawowym jest unormowanie ujęte w art. 154 ust. 1 i 2 Konstytucji RP, w którym inicjatywa powołania rządu została oddana w ręce Prezydenta RP. To właśnie głowie państwa powierzone zostało prawo desygnowania kandydata na premiera, który następnie przedstawia mu proponowany skład Rady Ministrów. Konstytucja w sposób formalny nie ograniczyła swobody wyboru Prezydenta, może on więc wskazać dowolną osobę. Jeżeli jednak desygnowany kandydat nie będzie miał potencjału politycznego gwarantującego mu możliwość późniejszego uzyskania wotum zaufania Sejmu, to nie zostanie on premierem rządu. W konsekwencji więc działania podejmowane przez głowę państwa muszą uwzględniać postawę partii będących w Sejmie i dysponujących możliwością uzyskania pożądanej większości głosów (samodzielnie bądź też w porozumieniu z innymi partiami).

Jeżeli Prezydent zaakceptuje skład rządu proponowany przez kandydata desygnowanego na premiera, możliwe będzie formalne powołanie Prezesa Rady Ministrów i pozostałych członków rządu oraz odebranie od nich przysięgi. Regulacja konstytucyjna wymaga, aby nastapiło to w terminie $14 \mathrm{dni}$ od dnia pierwszego posiedzenia Sejmu lub też przyjęcia dymisji poprzedniej Rady Ministrów (art. 154 ust. 1 Konstytucji RP).

Po złożeniu przysięgi przed premierem nowo powołanego rządu jest jeszcze jedno zadanie, niezbędne dla zapewnienia trwałości misji jego gabinetu. Konstytucja - zgodnie z regułami parlamentarnego systemu rządów ${ }^{19}$ - wymaga bowiem, aby każdy rząd cieszył się zaufaniem Sejmu. W związku z powyższym Prezes Rady Ministrów w terminie 14 dni od powołania jego gabinetu przez Prezydenta winien przedstawić Sejmowi program działania rządu (exposé) i uzyskać wotum zaufania wyrażone bezwzględną większością głosów w obecności co najmniej połowy ustawowej liczby posłów (art. 154 ust. 2 Konstytucji RP).

Jeżeli jednak Prezydent nie zaakceptuje kandydatów na członków rządu wskazanych przez desygnowanego przez siebie kandydata albo też Rada Ministrów powołana przez głowę państwa nie uzyska sejmowej inwestytury, to nastapi niezwłoczne przejście do drugiego trybu powoływania rządu (pierwszego rezerwowego), który został unormowany w art. 154 ust. 3 Konstytucji RP. W takim przypadku inicjatywa przechodzi w ręce Sejmu, który - w terminie 14 dni - sam powołuje premiera i proponowanych przez niego członków Rady Ministrów. Tak powoływany rząd również winien uzyskać wotum zaufania

${ }^{18}$ O procedurze tworzenia rządu w świetle regulacji Małej Konstytucji z 1992 r. zob. J. Juchniewicz, Idea stabilności rzqdu w polskich rozwiazaniach ustrojowych po 1989 r., w: E. Hull, E. Sokalska (red.), Państwowość konstytucyjna XIX i XX wieku, Olsztyn 2015, s. 81-82.

19 Zob. A. Lijphart, op. cit., s. 106. 
wyrażone bezwzględną większością głosów w obecności co najmniej połowy ustawowej liczby posłów. W przypadku uzyskania takiego poparcia posłów Prezydent powołuje Radę Ministrów i odbiera od niej przysięgę.

Jeżeli jednak przy zastosowaniu powyżej opisanych procedur nie uda się powołać rządu, to pozostanie do wykorzystania ostatnia procedura (druga rezerwowa), opisana w art. 155 Konstytucji RP. Inicjatywa w zakresie powołania Rady Ministrów będzie - ponownie - w gestii Prezydenta. To właśnie Prezydent powoła Prezesa Rady Ministrów i - na jego wniosek - pozostałych członków rządu i przyjmuje od nich przysięgę. Również i tak powołana Rada Ministrów będzie musiała - w terminie 14 dni od swego powołania - uzyskać wotum zaufania Sejmu, w tym przypadku jednak skuteczne będzie udzielenie wotum zaufania większością głosów w obecności co najmniej połowu ustawowej liczny posłów.

Jeżeli jednak również i w tym trybie Rada Ministrów nie uzyska poparcia Sejmu, to konsekwencją będzie skrócenie kadencji Sejmu przez Prezydenta i niezwłoczne zarządzenie nowych wyborów do Sejmu i Senatu RP.

W polskiej praktyce ustrojowej, na gruncie obecnie obowiąującej Konstytucji RP aż do 2004 r. nie wystapiła potrzeba skorzystania z procedur rezerwowych, dlatego też w literaturze przedmiotu wyrażany był pogląd o ich niewielkim znaczeniu ${ }^{20}$. Jednak przykład powoływania rządu Marka Belki pokazuje, że może zaistnieć sytuacja, w której Rada Ministrów, nie uzyskując wotum zaufania zgodnie z procedurami opisanymi przez art. 154 Konstytucji RP, poparcie Sejmu uzyska dopiero w głosowaniu przeprowadzonym w trybie art. 155 Konstytucji $\mathrm{RP}^{21}$.

Wymóg każdorazowego uzyskania akceptacji posłów jest istotną gwarancją sprawnego funkcjonowania rządu w przyszłości. Słusznie się jednak podkreśla w doktrynie, że głosowanie w drugiej procedurze rezerwowej związane jest także z koniecznością rozważenia przez posłów, czy skłonni są zaakceptować zaproponowany skład Rady Ministrów, czy też jednak decydują się na skrócenie kadencji Sejmu ${ }^{22}$.

V. Istota systemu parlamentarnego opiera się na dysponowaniu przez rząd zaufaniem parlamentarnym, jedynie bowiem w takim przypadku kolegialny organ władzy wykonawczej może stabilnie i efektywnie sprawować

${ }^{20}$ Zob. R. Mojak, Kształtowanie składu Rady Ministrów w świetle przepisów i praktyki ustrojowej, Lublin 2003, s. 8.

${ }^{21}$ Warto zaznaczyć, że w przypadku powołania rządu M. Belki Sejm nie skorzystał z możliwości samodzielnego wyboru premiera i wskazanego przez niego składu rządu. Tak więc po nieudanej próbie uzyskania inwestytury w trybie pierwszym (bezwzględną większością głosów) pominięta została pierwsza procedura rezerwowa i rząd został powołany w drugiej procedurze rezerwowej i przy poparciu przekraczającym zwykłą większość głosów posłów; zob. M. Grzybowski, System rzqdów w Rzeczypospolitej Polskiej: charakterystykami diagnoza watpliwości. Uwagi wprowadzajace, „Przegląd Prawa Konstytucyjnego” 2012, nr 1, s. 137.

${ }^{22}$ Zob. T. Litwin, Zasada odpowiedzialności Rady Ministrów przed parlamentem - rzad mniejszościowy w polskiej praktyce parlamentarnej, w: K. Górka, T. Litwin (red.), Konstytucja Rzeczypospolitej Polskiej. Próba oceny i podsumowania z perspektywy dziesięciolecia stosowania, Kraków 2008, s. 70. 
swoją funkcję ${ }^{23}$. Utrata zaufania większości sejmowej wobec rządu jest więc przesłanką umożliwiająca wystapienie $\mathrm{z}$ wnioskiem o odwołanie rządu. I tak jak wotum zaufania udzielane $\mathrm{w}$ procedurach powoływania rządu jest potwierdzeniem, że nowo tworzona Rada Ministrów dysponuje poparciem odpowiedniej liczby posłów, tak procedura udzielenia wotum nieufności oznacza, że rząd poparcie to utracił. W ten sposób realizowana jest procedura kontroli parlamentarnej ${ }^{24} \mathrm{i}$ odpowiedzialności politycznej kolegialnego organu egzekutywy przed Sejmem ${ }^{25}$.

Jednakże specyfika systemu parlamentarnego ${ }^{26}$ pokazuje, że łatwiejsza do utworzenia jest zazwyczaj „koalicja negatywna” aniżeli „koalicja pozytywna”. Częściej więc politycy partii należących nawet do dalekich od siebie nurtów sceny politycznej będą zainteresowani udziałem w odwołaniu aktualnie rządzacych niż podejmowaniem wspólnych działań na rzecz utworzenia nowej, stabilnej większości. W konsekwencji mogłoby więc dojść do sytuacji, w której stanie się możliwe odwołanie rządu, ale nie będzie można powołać nowego ${ }^{27}$. Dla uniknięcie takich sytuacji normy konstytucyjne wprowadzają instytucję, którą doktryna określa jako „konstruktywne wotum nieufności”"28. Jest to więc mechanizm, który ma „na celu ochronę rządu przed skutkami działań przypadkowych w większości negatywnych"29.

Polska regulacja konstruktywnego wotum nieufności została ujęta w art. 158 Konstytucji RP ${ }^{30}$, a „konstruktywność” przyjętego mechanizmu wi-

${ }^{23}$ Zob. też M. Wyrzykowski, Osiem tez w sprawie systemu rzqdów premierowskich, w: Administracja publiczna w państwie prawa. Księga Jubileuszowa dla Profesora Jana Jendrośki, Wrocław 1999, s. 435.

${ }^{24}$ Szerzej na temat funkcji kontrolnej Sejmu zob. M. Kruk, Funkcja kontrolna Sejmu RP, Warszawa 2008, passim, oraz J. Juchniewicz, Instrumenty realizacji funkcji kontrolnej Sejmu próba oceny skuteczności, „Przegląd Prawa Konstytucyjnego” 2013, nr 1(13), s. 15-32.

${ }^{25}$ Funkcja kontrolna została konstytucyjnie przyporządkowana Sejmowi, senatorowie jednak mogą w pewnym zakresie wykonywać określone czynności kontrolne, zob. J. Szymanek, Rola Senatu RP w wykonywaniu kontroli parlamentarnej (uwagi de lege lata $i$ de lege ferenda), „Ruch Prawniczy, Ekonomiczny i Socjologiczny" 66, 2004, z. 1, s. 15 i n.

${ }^{26}$ Poza przedmiotem rozważań pozostawiam - warte jednak głębszej analizy - kwestie emocji i osobowości polityków zasiadających w izbie.

${ }^{27}$ Zob. P. Winczorek, Komentarz do Konstytucji Rzeczypospolitej Polskiej z dnia 2 kwietnia 1997 roku, Warszawa 2008, s. 321. Ten element racjonalizacji systemu parlamentarnego umieszczony po raz pierwszy w Ustawie zasadniczej RFN z 1949 r. stał się typowym mechanizmem wprowadzanym do konstytucji państw Europy Środkowej i Wschodniej po przemianach ustrojowych lat dziewięćdziesiątych; zob. E. Tanchev, Parliamentarism rationalized, „East European Constitutional Review" 2(1), 1993, s. 33-34.

${ }^{28}$ Jest to pojęcie stworzone przez doktrynę prawa konstytucyjnego, niestosowane wprost w treści regulacji konstytucyjnych; zob. S. Patyra, Konstruktywne wotum nieufności jako formuła tworzenia i dymisji Rady Ministrów, „Przegląd Sejmowy” 2001, nr 1(42), s. 17.

${ }^{29}$ Zob. R. Mojak, Parlament a rząd w ustroju Trzeciej Rzeczypospolitej Polskiej, Lublin 2007, s. 558.

${ }^{30}$ Polska konstrukcja konstruktywnego wotum nieufności odbiega jednak od niemieckiego wzorca, dlatego niektórzy autorzy stosowali nazwę „nieregularne konstruktywne wotum nieufności”; zob. Z. Czeszejko-Sochacki, Prawo parlamentarne w Polsce, Warszawa 1997, s. 172. O różnicach w recepcji wzorca niemieckiego zob. M. Pach, Recepcja konstruktywnego wotum nieufności. Artykut 67 Ustawy zasadniczej Republiki Federalnej Niemiec w konfrontacji z rozwiazaniami ustrojowymi Hiszpanii, Belgii, Stowenii, Węgier i Polski, „Studia Iuridica Toruniensia” 14, 2014, s. 273 i n. 
doczna jest zarówno w odniesieniu do samego momentu składania wniosku, jak i też przeprowadzania głosowania. Konstruktywność wniosku polega na konieczności wskazania - wraz z podpisami co najmniej 46 posłów ${ }^{31}$ - nazwiska nowego kandydata na urząd premiera ${ }^{32}$. Natomiast elementem „konstruktywności" głosowania jest unormowanie wskazujące, że dla przyjęcia złożonego wniosku musi on zostać poparty przez większość ustawowej liczby posłów (czyli minimum 231). Wymóg ten sprawia, że powołany w tym trybie rząd dysponuje poparciem zapewniającym mu stabilne funkcjonowanie ${ }^{33}$.

Złożony wniosek może być poddany pod głosowanie nie wcześniej niż po upływie 7 dni od jego zgłoszenia i nie później niż na kolejnym posiedzeniu Sej$\mathrm{mu}^{34}$. Czas ten ma umożliwić rządowi i posłom przeprowadzenie niezbędnych konsultacji związanych $\mathrm{z}$ odwołaniem jednego i ewentualnym powołaniem drugiego rządu, a także pozwolić uniknąć podejmowania pochopnych decyzji wyłącznie pod wpływem emocji ${ }^{35}$. Jeżeli zgłoszono równolegle więcej niż jeden wniosek o wotum nieufności, to są one rozpatrywane łącznie. Poddanie ich pod głosowanie następuje jednak indywidualnie, zgodnie z kolejnościa, w jakiej były zgłaszane. W przypadku uchwalenia jednego wniosku pozostałe stają się bezprzedmiotowe i nie sa poddawane pod głosowanie.

Regulacją wzmacniająca stabilność funkcjonowania rządu jest także norma wprowadzająca ograniczenie możliwości wystapienia z powtórnym wnioskiem, jeżeli poprzednio zgłoszony został przez Sejm odrzucony. W takim przypadku nowy wniosek nie może zostać zgłoszony przez kolejne 3 miesiące, chyba że zostanie zgłoszony przez grupę posłów licząca co najmniej 115 osób. Wprowadzenie takiej blokady czasowej uzasadniane jest koniecznością ograniczenia możliwości wykorzystywania instytucji wotum nieufności przez stosunkowo małe grupy opozycyjne, zgłaszające wnioski jedynie „dla koniunkturalnych celów politycznych czy dla doraźnego efektu propagandowego" 36 .

${ }^{31}$ Po złożeniu wniosku nie można już podpisów wycofać ani też nie można złożyć nowych.

${ }^{32}$ Brak jest prawnego wymogu przedłożenia zgody kandydata, dlatego R. Mojak przyjmuje, że kwestia ta jest objęta domniemaniem „wyrażenia zgody przez określoną osobę na wybór na stanowisko premiera, jeśli we wniosku pojawia się wskazanie kandydata” (R. Mojak, Parlament a rzad ..., s. 564). Wydaje się jednak, że stanowisko to jest błędne - kandydat wskazany we wniosku musi jednoznacznie akceptować inicjatywę jego wyboru na urząd premiera. Akceptacja ta może zostać wyrażona w sposób domniemany, np. przez merytoryczną aktywność kandydata, ale jeżeli pojawiłyby się wątpliwości, to winny one zostać rozstrzygnięte przed poddaniem wniosku pod głosowanie. Wydaje się, że właściwym trybem w takim przypadku będzie działanie Marszałka Sejmu mające na celu formalną kontrolę wniosku.

${ }^{33}$ Zob. B. Dziemidok-Olszewska, Konstruktywne wotum nieufności w Republice Federalnej Niemiec i III Rzeczypospolitej Polskiej, „Środkowoeuropejskie Studia Polityczne” 2017, nr 2, s. 102.

${ }^{34}$ Doktryna bardzo pozytywnie oceniła 7-dniowy termin minimalny, z krytyką spotkało się jednak określenie terminu maksymalnego na przeprowadzenie głosowania. Podkreśla się, że w skrajnych przypadkach (np. zaplanowane wakacje parlamentarne) głosowanie w sprawie wniosku mogłoby się odbyć po 2 (lub nawet więcej!) miesiącach od jego wniesienia; zob. W. Sokolewicz, uwagi do art. 158, w: L. Garlicki (red.), Konstytucja Rzeczypospolitej Polskiej. Komentarz, t. 1, Warszawa 1999, s. 39.

${ }^{35}$ Zob. Z. Szeliga, Odpowiedzialność parlamentarzystów, Prezydenta, Rady Ministrów oraz jej członków w świetle Konstytucji RP z 2 kwietna 1997 roku, Lublin 2003, s. 87.

${ }^{36}$ R. Mojak, Parlament a rzqd..., s. 562. 
Wniosek poselski wyrażający brak zaufania dla rządu może się opierać na różnych przesłankach i w efekcie może być nie tylko konsekwencją negatywnej oceny działalności rządu, lecz także wynikać np. ze zmiany układów koalicyjnych w izbie. Instytucja ta może być także wykorzystana przez aktualnie rządzącą większość jako mechanizm ułatwiający rekonstrukcję rządu ${ }^{37}$.

VI. Wyłomem w recypowaniu niemieckiego wzorca wzmocnienia rządu (w tym zwłaszcza szefa rządu) jest jednak pozostawienie możliwości przeprowadzenia procedury indywidualnego wotum nieufności wobec ministra ${ }^{38}$. Dlatego też dla zapewnienia możliwości stabilnego funkcjonowania Rady Ministrów należy zrezygnować z selektywnego wotum nieufności kierowanego przeciwko wybranemu ministrowi. Instytucja ta jest bowiem sprzeczna z koncepcją wzmocnienia Rady Ministrów jako zintegrowanego ciała pracującego pod przewodnictwem Prezesa Rady Ministrów i ponoszącego solidarną odpowiedzialność w procedurze konstruktywnego wotum nieufności ${ }^{39}$.

Praktyka ostatnich kadencji Sejmu wykazuje także, że składane wnioski o udzielenie dymisji ministrowi maja jedynie charakter demonstracji politycznych aktualnej mniejszości sejmowej, nie są zaś efektem merytorycznej oceny pracy danego ministra. Tym bardziej negatywnie należy ocenić zgłoszenie indywidualnych wniosków o odwołanie wszystkich (lub prawie wszystkich) ministrów. Postępowanie takie w sposób oczywisty jest działaniem przeciwko ratio legis tej instytucji. Co więcej-oznaczałoby, że wnioskodawcy negatywnie oceniaja cały rząd, ale jednocześnie wyrażają swoje zaufanie wobec premiera ${ }^{40}$.

VII. Konstytucja RP z 1997 r. stała się dokumentem ustrojowym, w którym zrealizowany został zamiar wzmocnienia kolegialnego członu władzy wykonawczej, w szczególności premiera. Jest to zauważalne podczas analizy norm prawnych określających zasady zarówno powoływania, jak i odwoływania rządu. Co jednak ważne - twórcy Konstytucji pozostali w ramach zasady podziału władz i ,zachowali balans między koniecznością zapewnienia rządowi warunków do stabilnego działania a zagwarantowaniem opozycji prawa do reagowania i uruchamiania instrumentów mogacych doprowadzić do dymisji gabinetu" 41 .

Wydaje się także, że jako uwagę de lege ferenda należy podnieść celowość (i konieczność) rezygnacji z możliwości stosowania indywidualnego wotum nieufności. Należy jednak podkreślić, że nie musiałoby to oznaczać całkowitego pozbawienia posłów możliwości wyrażenia swego stanowiska wobec osoby

${ }^{37}$ Zob. M. Kruk, Idea stabilności i efektywności rzqdów..., s. 420.

${ }^{38}$ Pozostawienie tej instytucji w Konstytucji z 1997 r. było krytykowane już podczas prac w Komisji Konstytucyjnej Zgromadzenia Narodowego; zob. D. Dudek, Komentarz do art. 159, w: M. Safjan, L. Bosek (red.), Konstytucja RP, t. 2: Komentarz do art. 87-243, Warszawa 2016.

${ }_{39}$ Zob. R. Balicki, Relacje między organami wtadzy wykonawczej- na drodze do systemu kanclerskiego, w: B. Banaszak, M. Jabłoński (red.), Konieczne i pożadane zmiany Konstytucji RP z 2 kwietnia 1997 roku, Wrocław 2010, s. 329.

${ }^{40}$ Zob. B. Banaszak, Konstytucja Rzeczypospolitej Polskiej. Komentarz, Warszawa 2009, s. 735 .

${ }^{41}$ J. Juchniewicz, Idea stabilności rzqdu..., s. 90. 
ministra. W modelu niemieckim ukształtowała się bowiem instytucja „wniosku o odwołanie ministra”, z którym izba może wystapić do kanclerza. Jednak w przypadku zgłoszenia takiego wniosku ostateczna decyzja co do przyszłości ministra pozostaje wyłącznie w gestii szefa rządu ${ }^{42}$.

Doświadczenia dwudziestu lat funkcjonowania Konstytucji z 1997 r. ukazuja, że jest to nowoczesny i dobrze zaprojektowany akt prawny, który pozwala na sprawne i stabilne funkcjonowanie organów państwowych. Jednakże jedynym warunkiem gwarantującym osiagnięcie tego celu jest przestrzegania postanowień Konstytucji i funkcjonowanie zgodnie z zasadami w niej zawartymi.

dr Ryszard Balicki

Uniwersytet Wroctawski

ryszard.balicki@uwr.edu.pl

\section{CONSTITUTIONAL GUARANTEES FOR THE STABILITY OF THE COUNCIL OF MINISTERS}

$$
\text { Sum mary }
$$

The article deals with the stability of the functioning of a collegial body of the executive power - the government. The stability of the executive power, together with citizens' participation in the elections and maintenance of political order, is one of the elements of a broader concept of a state's political stability. Historical experiences (especially those of the French Third and the Fourth Republic and Italy) demonstrate the importance of stable and effective functioning of a government. Relating the issue in question to the Polish model of government, the author analyses constitutional norms laying down the principles of appointing the Council of Ministers and the possibilities of its dismissal.

${ }^{42}$ Zob. K. von Beyme, Die parlamentarische Demokratie Entstehung und Funktionsweise 1789-1999, Wiesbaden 2014, s. 216. 
